\title{
POTENSI FAMILI ASTERACEAE SEBAGAI OBAT TRADISIONAL DI MASYARAKAT ETNIS SIMALUNGUN KABUPATEN SIMALUNGUN PROVINSI SUMATERA UTARA
}

\section{Potential Family Asteraceae As A Traditional Medicine In The Ethnic Society Simalungun Province North Sumatera}

\author{
Helen Anjelina Simanjuntak \\ Program Studi S-I Farmasi, Sekolah Tinggi Ilmu Kesehatan Senior Medan \\ Jalan Jamin Ginting No.13 KM 8,5 Padang Bulan, Medan \\ *Corresponding author: Email : helenanjelinas@gmail.com
}

\begin{abstract}
Abstrak
Simalungun merupakan salah satu kabupaten di provinsi sumatera utara yang memiliki beragam etnis salah satunya etnis simalungun. Masyarakat etnis simalungun masih menggunakan bahan-bahan alam seperti tumbuh-tumbuhan dalam pengobatan berbagai macam penyakit. Dari penelitian yang telah dilakukan ditemukan beberapa jenis tumbuhan yang berpotensi sebagai obat tradisional yang didominasi oleh jenis-jenis famili Asteraceae. Terdapat 10 jenis tumbuhan famili Asteraceae yang berpotensi sebagai obat tradisional yaitu: Achillea santolina, Ageratum conyzoides, Cosmos caudatus, Eclipta alba, Emilia sonchifolia, Eupatorium riparium, Gynura segetum, Sonchus arvensis, Tithonia diversifolia, dan Wedelia calendulaceae. Potensi obat tersebut antara lain sebagai Obat sakit perut, Obat Luka, Penambah Nafsu makan, Penyubur Rambut, Peluruh Air Seni, Hipertensi, dan Batu Ginjal. Bagian tumbuhan yang digunakan adalah bagian Daun.
\end{abstract}

Kata kunci: Simalungun, Asteraceae, Tradisional, Obat.

\begin{abstract}
Simalungun is one of the regencies in North Sumatera province that has various ethnic one of them is Simalungun ethnic. The ethnic community simalungun still use natural materials such as plants in the treatment of various diseases. From the research that has been done found some types of plants that have potential as a traditional medicine that is dominated by the types of Asteraceae family. There are 10 species of Asteraceae family that have potential as traditional medicine: Achillea santolina, Ageratum conyzoides, Cosmos caudatus, Eclipta alba, Emilia sonchifolia, Eupatorium riparium, Gynura segetum, Sonchus arvensis, Tithonia diversifolia, and Wedelia calendulaceae. Potential drugs such as Abdominal pain medication, Drug Injury, Appetite Enhancer, Hair Fertilizer, Peluruh Air Art, Hypertension, and Kidney Stone. Plant part used is part of Leaf.
\end{abstract}

Keywords: Simalungun, Asteraceae, Traditional and Medicine

How to Cite: Simanjutak, H.A., 2017. Potensi Famili Asteraceae Sebagai Obat Tradisional Di Masyarakat Etnis Simalungun Kabupaten Simalungun Provinsi Sumatera Utara, BioLink, Vol. 4 (1) Hal. 11-18 


\section{PENDAHULUAN}

Indonesia merupakan wilayah kekayaan biodiversitas dunia terbesar kedua, termasuk kekayaan ragam tumbuhan obat dan ribuan spesies sudah digunakan masyarakat. Berbagai suku memanfaatkan tumbuhan sebagai bahan etnomedisin dengan keunikan ramuan dan cara penyajian yang menunjukkan tingginya pengetahuan etnis lokal tentang tumbuhan obat (Evizal et al., 2013).

Etnis simalungun merupakan salah satu etnis yang terdapat di Kabupaten Simalungun Provinsi Sumatera Utara. Masyarakat Etnis Simalungun masih memanfaatkan tumbuh-tumbuhan sebagai alternatif pengobatan suatu penyakit. Dari penelitian sebelumnya telah diperoleh jenis tumbuhan yang mendominasi adalah tumbuhan dari Famili Asteraceae.

Famili Asteraceae merupakan anggota famili terbesar kedua dalam sistem kingdom plantae (Lawrence, 1958). Famili Asteraceae juga mendominasi vegetasi tumbuhan di bumi dengan jumlah anggota yaitu lebih dari 24.000 - 30.000 spesies dan 1600 - 1700 genera yang tersebar hampir di seluruh dunia serta mendiami kawasan hampir di semua lingkungan (Bisht \& Purohit, 2010).

Secara morfologi anggota dari famili Asteraceae memiliki ciri daun tersebar atau berhadapan, tunggal. Bunga dalam bongkol kecil dengan daun pembalut, sering dalam satu bongkol yang sama terdapat dua macam bunga yaitu bunga cakram berbentuk tabung dan bunga tepi berbentuk pita, termasuk ke dalam gulma berdaun lebar, hidup secara terresterial, termasuk kedalam dicotyledoneae, berkembangbiak secara simple perennial. Daun pelindung dari bunga tersendiri kadang-kadang seperti sisik jerami. Bunga beraturan atau setangkup tunggal dengan kelopak yang umumnya sangat tidak jelas. Mahkota berdaun lepas, benang sari dalam tabung mahkota, bakal buah tenggelam dengan satu bakal biji, tangkai putik satu, kebanyakan dengan dua kepala putik. Buah keras berbiji satu, biji umumnya tumbuh bersatu dengan kulit buah (Tjitrosoepomo, 2010).

Beberapa jenis tanaman famili Asteraceae dapat dimanfaatkan sebagai obat tradisional, hal ini disebabkan karena famili Asteraceae memiliki komponen senyawa bioaktif, seperti seskuiterpen, lakton, triterpen pentasiklik, alkohol, alkaloid, tanin, polifenol, saponin, dan sterol yang dapat digunakan untuk bahan pengobatan (Wegiera et al., 2012).

\section{METODE PENELITIAN}

Penelitian ini dilaksanakan pada bulan Januari - Mei 2017, menggunakan metode survei eksploratif dengan variabel bebas informan/Battra (Pengobat Tradisional). Pengumpulan data dilakukan dengan teknik wawancara secara mendalam terhadap informan/Battra (pengobat tradisional) mengenai nama lokal tumbuhan, bagian tumbuhan yng diambil serta cara meramunya.

Observasi lapangan seperti identifikasi tumbuhan, habitat, keadaan demografi, dokumentasi foto dan pengambilan sampel spesimen. Spesimen tanaman obat diambil untuk deskripsi 
morfologi, pengawetan dan pembuatan herbarium. Deskripsi morfologi dilakukan dengan mencatat bagian penting morfologi tumbuhan seperti; perawakan, akar, daun, batang dan bunga. Pengawetan dilakukan dengan spiritus untuk pengawetan basah sedangkan pengawetan kering dilakukan di herbarium.

\section{HASIL DAN PEMBAHASAN}

Berdasarkan hasil penelitian yang telah dilakukan didapatkan 10 jenis tumbuhan dari famili Asteraceae yang berpotensi sebagai obat tradisional yang terdiri dari: Achillea santolina, Ageratum conyzoides, Cosmos caudatus, Eclipta alba, Emilia sonchifolia, Eupatorium riparium, Gynura segetum, Sonchus arvensis, Tithonia diversifolia, dan Wedelia calendulaceae.

Achillea santolina, nama lokal Daun seribu. Tumbuhan ini termasuk tumbuhan Semak. Bentuk batang masif, bulat, berbuku dan hijau. Bentuk Daun majemuk, menyirip ganda, duduk memeluk batang, ujung bulat atau tumpul, pangkal menyempit, panjang 30$35 \mathrm{~cm}$, lebar 1-5 cm, berwarna hijau. Bentuk bunga majemuk, di ujung batang, bentuk kerucut, putik menjulang keluar, mahkota 5, putih, bergerigi tumpul, bentuk tabung tiga samapi sepuluh, berwarna putih. Bentuk buah kecil, lonjong berwarna coklat. Bentuk biji bulat, pipih dan berwarna hitam. Tipe akar tunggang berwarna cokelat muda (Tjitrosoepomo, 2010).

Daun berkhasiat sebagai obat sakit perut. Ramuan untuk obat sakit perut; diambil 10 gram daun segar Achillea santolina, dicuci terlebih dahulu, lalu direbus dengan 1 gelas air selama kurang lebih 15 menit, setelah dingin lalu disaring. Hail saringan diminum 2 kali selang waktu 3 jam. Daun Achillea santolina, mengandung saponin, flavonoid, minyak atsiri dan akarnya mengandung polifenol.

Ageratum conyzoides, nama lokal bebandotan. Tumbuhan ini termasuk dalam tumbuhan herba. Bentuk batang bulat, permukaan batang kasar dan dipenuhi rambut-rambut halus, arah tumbuh batang tegak lurus, warna batang hijau kekuningan. Susunan daun berhadapan bersilang, struktur daun tunggal, bentuk daun bulat telur, ujung daun runcing, pangkal daun membulat, tepi daun bergerigi, susunan tulang daun menyirip, daun berwarna hijau dan berwarna kuning, Bagian daun terdiri atas helaian daun yang ditopang oleh tangkai daun. Kedua permukaan daun berambut dengan kelenjar yang terletak dibawah permukaan daun. Perbungaan tumbuhan ini yaitu bongkol majemuk payung. Bunga terletak dibagian terminal dan aksilar. Bunga bongkol pada tumbuhan ini terdiri atas bunga tabung saja. Bunga tabung dilindungi oleh sekumpulan daun-daun pelindung yang berlekatan sehingga membentuk bongkol dengan menyatu menjadi karangan. Pada daun pelindung terdapat rambut-rambut halus. Bagian petal bunga tabung berwarna ungu atau putih. Buah berwana hitam dan dilengkapi dengan rambut halus dan pendek (Tjitrosoepomo, 2010).

Daun Ageratum conyzoides berkhasiat sebagai obat luka. Ramuan untuk obat luka: diambil 5 gram daun segar Ageratum conyzoides, dicuci dan 
ditumpuk sampai lumat, kemudian ditempelkan pada luka dan dibalut. Daun Ageratum conyzoides mengandung beberapa senyawa metabolit sekunder diantaranya golongan terpenoid, fenolik dan alkaloid (Desiarianthy, 2009). Alkaloid yang terdapat pada daun Ageratum conyzoides memiliki efek farmakologi sebagai antibakteri (Suranintyas et al., 2008).

Cosmos caudatus, nama lokal kenikir. Tumbuhan ini termasuk kategori perdu. Bentuk batang tegak, segi empat, beralur membujur, bercabang banyak, beruas, berwarna hijau keunguan. Bentuk daun majemuk, bersilang berhadapan, berbagi menyirip, ujung runcing, tepi rata, berwarna hijau. Bentuk bunga majemuk, bentuk bongkol di ujung batang, mahkota terdiri dari 8, berwarna merah, benang sari berbentuk tabung, kepala sari berwarna cokelat kehitaman, putik berambt, hijau kekuningan dan merah. Bentuk buah keras, bentuk jarum, ujung berambut, masih muda hijau sudah tua berwarna cokelat. Bentuk biji keras, kecil bentuk jarum berwarna hitam. Bentuk akar tunggang dan berwarna putih (Bhattacharyya, (2014).

Daun Cosmos caudatus, berkhasiat sebagai penambah nafsu makan. Ramuan obat penambah nafsu makan; dipakai 100 gram daun segar Cosmos caudatus, dicuci bersih dan dimakan sebagai lalap. Daun Cosmos caudatus, mengandung fenolat, flavonoid, karbohidrat, protein, mineral, dan vitamin yang dapat meningkatkan nilai gizi (Abas, 2003).

Eclipta alba, nama lokal urangaring. Tumbuhan ini tergolong kedalam herba. Bentuk batang bulat, bercabang, berambut putih dan ungu. Tipe daun tunggal, bulat telur, berseling berhadapan, ujung runcing, pangkal meruncing, tepi bergerigi, pertulangan menyirip, permukaan berambut dan hijau. Tipe bunga majemuk, bentuk bongkol, terletak diketiak daun dan diujung batang, tangkai panjang silindris, kelopak bentuk corong, ujung bertoreh enam, hijau, mahkota terdiri dari lima daun mahkota, kepala benang sari kuning, putik putih dan kuning. Buah berbentuk bulat telur berwarna hitam. Biji bentuk jarum berwarna hitam. Akar tunggang berwarna putih (Tjitrosoepomo, 2010).

Daun Eclipta alba, berkhasiat penyubur rambut. Ramuan penyubur rambut; diambil 10 gram daun Eclipta $a l b a$, dicuci dan ditumbuk, ditambahkan $1 / 2$ gelas air, kemudian diperas dan disaring. Hasil saringan dioleskan ke kulit kepala sambil dipijat-pijat. Daun Eclipta alba mengandung alkaloid, saponin, flavonoid dan tanin.

Emilia sonchifolia, nama lokal Tempuh wiyang. Tumbuhan ini termasuk tumbuhan herba. Tumbuhan ini mempunyai batang tegak lurus, bentuk batang bulat, berambut halus dan tangkai halus. Susunan bagian bawah beroset, sedangkan bagian atas berseling. Struktur daun tunggal. Daun berbentuk anak panah, pangkal daun tombak, ujung daun runcing, tepi daun berlekuk, ada juga yang rata, dan pertulangan daun menyirip. Perbungaan tumbuhan ini yaitu bongkol majemuk. Setiap perbungaan terdiri dari bunga tabung saja dengan petal berwarna ungu. Perbungaan terletak di ujung batang dan dilindungi oleh daun-daun pelindung. 
Buah keras dan berbentuk jarum. Akar tunggang berwarna putih (Bhattacharyya, (2014).

Daun Emilia sonchifolia berkhasiat sebagai obat peluruh air seni. Ramuan obat peluruh air seni; diambil 30 gram daun segar Emilia sonchifolia, dicuci dan direbus dengan 2 gelas air selama 15 menit. Air rebusan diminum sehari 2 kali dengan $1 / 2$ gelas pagi dan sore. Daun Emilia sonchifolia mengandung saponin, flavonoid dan polifenol.

Eupatorium riparium, nama lokal Teklan. Tumbuhan ini tergolong semak. Bentuk batang bulat, masih muda bersegi empat, beralur, beruas dan berwarna ungu. Bentuk daun tunggal berhadapan, bulat telur, tepi bergerigi, ujung dan pangkal runcing, permukaan berbulu halus, pertulangan menyirip, hijau muda, tangkai pendek daun berwarna hijau. Bentuk bunga majamuk, malai, tumbuh di ujung batang, kelopak bentuk lonceng, mahkota bunga bentuk jarum, dan putih. Bentuk buah kecil, berbulu, berwarna coklat hitam. Bentuk biji jarum, kecil dan berwarna hitam. Bentuk akar tunggang, dan coklat muda.

Daun Eupatorium riparium, berkhasiat sebagai obat peluruh air seni. Ramuan obat peluruh air seni; diambil 30 gram daun Eupatorium riparium, dicuci dan direbus dengan 2 gelas air selama 15 menit, hasil rebusan diminum sehari dua kali $1 / 2$ gelas pagi dan sore. Daun Eupatorium riparium mengandung saponin, tanin, kuinon dan steroid (Yunita, dkk., 2009).

Gynura segetum, nama lokal Daun Dewa. Tumbuhan ini tergolong semak. Bentuk batang lunak, penampang bulat, berambut halus, membentuk umbi berwarna ungu kehijauan. Tipe daun tunggal, bulat telur, tersebar mengelilingi batang, tangkai pendek, berdaging, berbulu lebat, tepi berotreh, pangkal meruncing, pertulangan menyirip, permukaan atas hijau, permukaan bawah ungu. Tipe bunga majemuk, bentuk bongkol, berbulu, kelopak hijau berbentuk cawan, benang sari berwarna kuning, bentuk jarum. Bentuk biji berbentuk jarum dan berwarna cokelat. Akar serabut dan berwarna kuning muda.

Daun Gynura segetum, berkhasiat sebagai obat hipertensi. Ramuan obat hipertensi; diambil 3 lembar daun Gynura segetum, direbus dengan 3 gelas air menjadi 2 gelas air, setelah dingin kemudian diminum. Daun Gynura segetum mempunyai kandungan kimia seperti alkaloid, flavonoid, tanin, steroid dan triterpenoid (Sayuthi et al, 2000). Efek farmakologis yang ditimbulkan sebagai antikoagulan, mencairkan bekuan darah, stimulasi darah, menghentikan pendarahan, menghilangkan panas dan menghentikan racun (Wijayakusuma, 1995). Zat aktif flavonoid memiliki efek dalam melancarkan peredaran darah ke seluruh tubuh dan mencegah terjadinya penyumbatan pada pembuluh darah (Setyoadi, 2010).

Sonchus arvensis, nama lokal Tempuyung. Tumbuhan ini tergolong herba. Bentuk batang bersegi, berlobang, bergetah putih, percabangan monopodial, berwarna hijau keputihputihan. Bentuk daun tunggal, bagian bawah membentuk reset akar, bentuk lonjong dan lanset, tepi rata, ujung meruncing, pangkal bertoreh berwarna 
hijau. Bentuk bunga majemuk, bentuk malai, kelopak betuk lonceng, berbulu, berwarna hijau keputih-putihan, mahkota bentuk jarum, putih, dan kuning keputih-putihan. Buah berbentuk kotak, berusuk lima, dan berambut hitam. Bentuk biji kecil berbentuk jarum dan berwarna hitam. Bentuk akar tunggang.

Daun Sonchus arvensis berkhasiat sebagai obat batu ginjal. Ramuan obat batu ginjal; direbus air 4 gelas, kemudian dimasukkan daun Sonchus arvensis, ditambahkan sedikit garam, kemudian direbus sampai menjadi 3 gelas, setelah dingin diminum. Dilakukan 3 kali sehari. Daun Sonchus arvensis mengandung asam fenolat, asam kafeat, flavonoid, terpena, kumarin, minyak atsiri, inositol, dan kalium yang tinggi (Pramono, dkk., 1993). Kalium yang tinggi pada daun Sonchus arvensis mengakibatkan kalsium karbonat terurai. Kalium akan menyingkirkan kalsium untuk bergabung dengan senyawa oksalat, karbonat atau urat yang merupakan pembentuk batu ginjal, sehingga endapan batu ginjal keluar bersama urine. Efek farmakologi yang telah diteliti adalah bahwa satu persen daun Sonchus arvensis dapat memperbesar kelarutan kalsium karbonat dan batu marmer secara in vitro dan diujikan langsung kepada penderita batu ginjal (Dhianawaty, dkk, 2003).

Tithonia diversifolia, nama lokal kembang bulan. Tumbuhan ini temasuk perdu. Bentuk batang tegak, bulat, berkayu, dan berwarna hijau.Bentuk daun tunggal, berseling, ujung dan pangkal runcing, pertulangan menyirip dan berwarna hijau. Bentuk bunga majemuk, diujung ranting, tangkai bulat, kelopak bentuk tabung, berbulu halus, hijau, mahkota lepas, bentuk pita, halus, kuning benang sari bulat, kuning putik melengkung dan kuning. Bentuk buah kotak, bulat, masih muda berwarna hijau dan setelah tua berwarna cokelat. Bentuk biji bulat, keras dan berwarna cokelat. Akar tunggang.

Daun Tithonia diversifolia, berkhasiat untuk obat sakit perut. Ramuan obat sakit perut; diambil 7 gram daun segar Tithonia diversifolia, dicuci dan direbus dengan 2 gelas air selama 25 menit, setelah dingin kemudian disaring. Hasil saringan diminum sekaligus. Daun Tithonia diversifolia mengandung triterpen/steroida, glikosida, saponin, dan flavonoida (Widari, 2005)

Wedelia calendulaceae, nama lokal Seruni. Tumbuhan ini tergolong herba. Bentuk batang tegak atau sedikit merunduk, bulat dan bercabang banyak dan membentuk stolon, kasar, dan berwarna hijau. Daun berbentuk tunggal, bersilang berhadapan, lonjong, ujung dan pangkal runcing, tepi bergerigi, permukaan berbulu dan berwarna hijau. Bentuk bunga tunggal di ketiak daun atau ujung batang, kelopak bentuk cawan, bertajuk 6, berwarna hijau, benang sari berkumpul ditengah bunga. Tipe buah buni, bulat telur, ujung kasar dan berwarna hitam. Biji berbentuk bulat telur, kecil dan berwarna hitam. Akar berbentuk tunggang.

Daun Wedelia calendulaceae, berkhasiat sebagai obat luka. Ramuan obat luka; diambil 15 gram daun Wedelia calendulaceae, dicuci dan ditumbuk halus kemudian ditempelkan pada bagian luka dan dibalut dengan kain bersih. Daun 
Wedelia calendulaceae, mengandung saponin, tanin dan flavonoid.

Bhattacharyya,

menyatakan bahwa senyawa kimia yang terdapat dalam famili Asteraceae adalah seskuiterpena, poliasetilena, Oleoresin, terpenoid, alkaloid, dan asam lemak.

Berdasarkan penelitian yang telah dilakukan, bagian organ tumbuhan yang banyak dimanfaatkan adalah bagian daun. Hal ini dikarenakan bagian daun mudah tumbuh kembali dan dapat dimanfaatkan secara terus menerus sampai tumbuhan tersebut tua dan mati (Zuhud \& Haryanto, 1994).

Handayani (2003), menjelaskan bahwa daun merupakan bagian (organ) tumbuhan yang paling banyak digunakan sebagai obat tradisional karena daun umumnya bertekstur lunak, memiliki kandungan air yang tinggi (70-80\%) dan merupakan tempat akumulasi fotosintat yang diduga mengandung unsur-unsur (zat organik) yang memiliki sifat dapat menyembuhkan penyakit, dan banyak memiliki kandungan seperti minyak atsiri, fenol, senyawa kalium, dan klorofil. Pemanfaatan bagian daun untuk obat lebih mudah cara pengolahannya.

\section{SIMPULAN}

Masyarakat Etnis Simalungun memanfaatkan tumbuhan-tumbuhan sebagai obat tradisional. Terdapat 10 jenis tumbuhan famili Asteraceae yang berpotensi sebagai obat tradisional yang terdiri dari Achillea santolina, Ageratum conyzoides, Cosmos caudatus, Eclipta alba, Emilia sonchifolia, Eupatorium riparium, Gynura segetum, Sonchus arvensis, Tithonia diversifolia, dan Wedelia calendulaceae. Bagian organ tumbuhan yang digunakan adalah bagian daun.

\section{DAFTAR PUSTAKA}

Abas, F. 2003. Antioxidative and Radical Scavening Properties Of The Constituents Isolated From Cosmos caudatus Kunth. Nat.Prod.Sci.245-248.

Bhattacharyya, B. 2004. Botani Sistematik 2. Penerbit Buku Kedokteran. Jakarta.

Bisht, V.K \& Purohit. V. 2010. Medicine and Aromatic Plants Diversity of Asteraceae in Uttarakhand. Herbal Research \& Development Institute. Gopeshwar. Uttarakhand.India. Nature and Science.

Desiarianty R. 2009. Aktivitas Antibakteri Ekstrak A. conyzoides L. terhadap S. aureus Secara in vitro. Universitas Pendidikan Indonesia: Bandung.

Dhianawati, D., K. Padmawinata., dan Iwang. S. 2003. Isolasi Karakterisasi Dan Uji Aktivitas Pencegahan Antikalkuli Luteolin 7-O-Glukosida Dari Daun Sonchus arvensis L. Pada Tikus Dengan Metode Matriks-Asam Glikolat. Jurnal Bionatura. Vol.5, No.3.

Evizal, R., Endah. R., Ardian., Agung, W. Deddy. A,. 2013. Keragaman Tumbuhan dan Ramuan Etnomidisin Lampung Timur. Prosiding Semirata FMIPA Universitas Lampung. Lampung.

Handayani, L. 2003. Membedah Rahasia Ramuan Madura. Jakarta: Agromedia Pustaka.

Naution, J., Masitah, P.D., Riyanto. 2016. Kajian Etnobotani Tumbuhan Obat Oleh Etnis Masyarakat di Dusun Aras Napal Kiri dan Dusun Aras Napal Kanan Desa Bukit Mas Kecamatan Besitang Kabupaten Langkat. Jurnal Biosains. Vol.2 No.2 Agustus 2016.

Lawrence. 1958. Taxonomi of Vascular Plants. Edisi Ke-3. New York: The Macmillan Company.

Pramono, S., Sumarno, S. Wahyono. 1993. Flavonoid Daun Sonchus arvensis L, Senyawa Aktif pembentuk Kompleks dengan Batu Ginjal Berkalsium. Warta Tumbuhan Obat Indonesia.

Sayuthi, D. Darusman, L.K. Suparto, I.H. Imanah, A. 20oo. Potensi senyawa bioaktif (Gynura pseudochina) Sebagai Antikanker. Tahap I. Buletin Kimia 1 (1).

Setyoadi dan Dina. D.W. Efek Lumatan Daun Dewa (Gynura segetum) dalam Memperpendek Waktu Penyembuhan 
Simanjuntak, H.A., Potensi Famili Asteraceae Sebagai Obat Tradisional di Masyarakat Etnis

Luka Bersih Pada Tikus. Jurnal Keperawatan Soedirman. Vol 5. No.3.

Sunarintyas S, Siswomihardjo W, Maryati, N. 2008. Pengaruh Konsentrasi Ekstrak Air dan Etanol Kulit Batang Azadirachta indica terhadap Penghambatan Pertumbuhan Streptococcus mutans. M. I. Kedokteran Gigi Universitas Gajah Mada Vol. 23, No. 4 .

Tjitrosoepomo. G. 2010. Taksonomi Tumbuhann Obat-obatan. UGM: Yogyakarta.

Wegiera. M. Helena, D.S. Marcin.J.D. Magdalena. K. And Kamila. K. 2012. Cytotoxic Effect of Some Medicinal Plants From Asteraceae Family. Chair and Departement Of Pharmaceutical Botany. Medical University. Vol.69. No.2.

Widari, 2005. Isolasi Senyawa Flavonoid Dari Daun Kembang Bulan (Tithonia diversifolia). USU. Medan

Wijayakusuma, H. 1995. Tanaman Berkhasiat Obat di Indonesia. Pustaka Kartini. Jakarta.

Yunita, E.A, Nanik. H.S., Jafron, W.H. 2009. Pengaruh Ekstrak daun Teklan (Euphatorium riparium) terhadap Mortalitas dan Perkembangan Larva Aedes aegypti. BIOMA. Vol 11. No.1

Zuhud, EAM dan Haryanto. 1994. Pelestarian Pemanfaatan Keanekaragaman Tumbuhan Obat Hutan Tropika Indonesia. Jurusan Konservasi Sumberdaya Hutan Fakultas Kehutanan IPB dan Lembaga Alam Tropika Indonesia (LATIN). Bogor. 